\title{
Bookshelf: Powerful Synergies: Gender Equality, Economic Development and Environmental Sustainability
}

\section{Blerta Cela, Irene Dankelman \& Jeffrey Stern}

To cite this article: Blerta Cela, Irene Dankelman \& Jeffrey Stern (2014) Bookshelf: Powerful Synergies: Gender Equality, Economic Development and Environmental Sustainability, Reproductive Health Matters, 22:43, 197-199, DOI: 10.1016/S0968-8080(14)43771-6

To link to this article: https://doi.org/10.1016/S0968-8080(14)43771-6

\section{(c) 2014 Reproductive Health Matters}

\section{Published online: 04 Jun 2014.}

Submit your article to this journal $\sqsubset$

Џll Article views: 1043

Q View related articles

View Crossmark data $\nearrow$

Citing articles: 2 View citing articles $\square$ 


\title{
Powerful Synergies: Gender Equality, Economic Development and Environmental Sustainability
}

\author{
Edited by: Blerta Cela, Irene Dankelman, Jeffrey Stern
}

United Nations Development Programme, July 2013

In English:

http://www.undp.org/content/dam/undp/library/gender/f_PowerfulSynergies2013_Web.pdf

In Russian:

http://www.undp.org/content/dam/undp/library/gender/PowerfulSynergies_RUS.pdf

\section{Introduction}

The globally shared vision for sustainable development has a strong gender dimension that highlights the need to continue identifying gender equality and women's empowerment as a core development goal in itself and as a catalyst for reaching all other goals and objectives. As the 2015 deadline for the Millennium Development Goals (MDGs) approaches, the United Nations is leading preparations for a post-2015 sustainable development agenda, both to accelerate achieving the MDGs and to create a framework that will build on the achievements of the past 15 years. The central challenge for the post-2015 sustainable development agenda is to move away from unsustainable policy frameworks, towards policies that encourage sustainable production and consumption, protect the most vulnerable and build resilience of countries and communities to climate and other environmental and socioeconomic risks. Building on the lessons learned from the MDGs, the processes underway to advance the post-2015 sustainable development agenda will be underpinned by the principles of inclusiveness, equality, human rights and sustainability, as well as by addressing the unequal measures of development progress.

In June 2012, the United Nations Conference on Sustainable Development (Rio+20) marked the twentieth anniversary of the United Nations Conference on Environment and Development (the Earth Summit). Launching a process for formulating new sustainable development goals towards 'The Future we Want', Rio+20 reflected the need for a renewed vision for sustainable development - a vision of increased livelihood security, equality and prosperity for all. United Nations Member States defined sustainable development broadly, emphasizing that reducing poverty and eliminating inequalities are as central as protecting the environment.

Despite many of the achievements of the MDGs, the framework has been criticized for inadequately addressing important issues embodied in the Millennium Declaration, particularly issues related to equality and environmental sustainability. While substantial progress has been made on many MDGs - for example, on education, poverty reduction and decreases of infant and child mortality persistent inequalities, including gender-based inequality, economic crises and widespread environmental degradation are holding back progress on many development goals. Progress has also been unequally distributed across and within regions and countries, further reflecting the interconnected nature of gender, age, class, ethnicity, education and rural-urban issues. People who have not benefitted or fallen deeper into poverty are the hardest to reach and include, in particular, women and children in remote and rural areas and in the poorest households. Often, their livelihoods are dependent on degrading natural resources; women still lack access to good quality land, property and inheritance rights; and genderbased violence and discrimination persist in many areas, hindering women's civic and political representation. Therefore, it is crucial that the forthcoming sustainable development goals mirror a 
broad vision of sustainable development and appropriately reflect the linkages among different goals and targets.

Across regions and countries, evidence suggests that development strategies that do not promote gender equality and the full participation and empowerment of women and girls will not succeed. This volume is a collection of contributions by gender and sustainable development experts who explore the interconnections among gender equality, economic development and environmental sustainability. These specialists offer insights, critiques, lessons learned and concrete proposals for promoting gender equality and women's empowerment in international and national sustainable development efforts. The authors address development challenges across a range of sectors and issues, such as energy, health, education, food security, climate change, human rights, consumption and production patterns, and urbanization.

The papers address gender issues within and across the social, economic and environmental dimensions of sustainable development, emphasizing the need to draw on both women's and men's perspectives to inform the green economy. Some papers demonstrate how women and their communities could benefit from gender-responsive climate change adaptation and mitigation policies. In exploring multiple facets of economic development, the papers discuss how sustainable forms of economic development and consumption patterns could strengthen women's resilience against natural disasters.

The authors advocate that investing in women and girls - in both rural and urban contexts will enhance gender equality, achieve more sustainable development and accelerate progress towards achieving the MDGs and the sustainable development framework that follows them. The authors stress the necessity and highlight the benefits of securing women's active participation in all stages of decision-making, ensuring their legal and political empowerment and including them in devising strong genderresponsive legal frameworks. The experts argue for supporting the specific needs of women as workers, entrepreneurs, home-based producers and consumers, and drivers of low-emission, climateresilient economies.

This publication aims to inspire policy makers and practitioners in the fields of environment, sustainable development and gender studies to support gender-responsive policy planning and implementation. The papers also provide evidence and recommendations for integrating gender equality into the post-2015 sustainable development discourse. Powerful Synergies underscores that, by acknowledging and acting on the critical, mutually reinforcing linkages between gender equality and sustainable development, we can create a society that maintains and regenerates the environment, respects human rights and provides women and men, girls and boys with the lives and future they deserve.

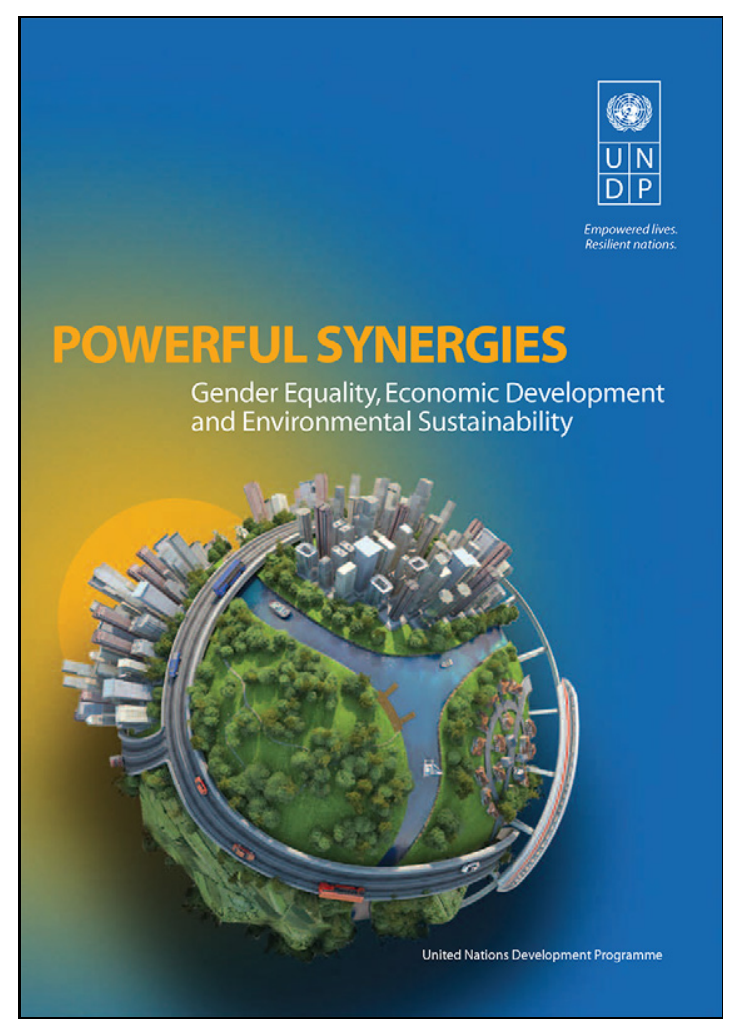

\section{Table of contents} GENDER EQUALITY AND SUSTAINABLE DEVELOPMENT

1. On the Road to Sustainable Development: Promoting Gender Equality and Addressing Climate Change IRENE DANKELMAN

Box 1. Creating a Development Framework for the Post-2015 Agenda GRAÇA MACHEL 
2. Missing in Action: Gender in International Environmental Law

PAOLO GALIZZI AND ALENA HERKLOTZ

Box 2. Convention on the Elimination of All Forms of Discrimination against Women Country Report Analysis of EnvironmentalSustainable Development Linkages ITZÁ CASTAÑEDA AND PIEDAD MARTIN

Box 3. What Are We Measuring?

ITZÁ CASTAÑEDA AND PIEDAD MARTIN

\section{GENDER EQUALITY, SUSTAINABLE CONSUMPTION AND THE 'GREEN ECONOMY'}

3. Gender, Growth and Adaptation to Climate Change STEPHAN KLASEN

4. Women, Consumption and Sustainable Development DIANE MACEACHERN

5. Population, Environment and Human Rights: a Paradigm in the Making GITA SEN AND ANITA NAYAR

Box 4. Promoting a Gender-Inclusive Green Economy BINA AGARWAL

Box 5. Can Economic Growth Support Gender Equality and Environmental Sustainability? DIANE ELSON

Box 6. Gender Equality Case Study: The Body Shop CHRISTINA ARCHER

\section{GENDER EQUALITY, ENERGY AND CLIMATE CHANGE}

6. Links between Gender Equality, Access to Sustainable Energy and Climate Change Mitigation Measures

GAIL KARLSSON AND ROSE MENSAH-KUTIN
7. Gender-Sensitive Strategies to Address the Challenges of Climate Change on Health and Nutrition Security CRISTINA TIRADO

8. Democratizing Financing for Sustainable Development: Gender Equality is the Key 119 LIANE SCHALATEK

Box 7. Gender and Climate Change Financing MARIAMA WILLIAMS

Box 8. Community Resilience Fund: Advancing Gender-Equitable, Pro-Poor, Sustainable Resilient Development SURANJANA GUPTA

\section{GENDER EQUALITY AND SUSTAINABLE DEVELOPMENT: SELECT PRIORITY AREAS}

9. Our Urban Future: Gender-Inclusive, Pro-Poor and Environmentally Sustainable? PRABHA KHOSLA

Box 9. Waste Pickers - A Gendered Perspective SONIA DIAS AND LUCIA FERNANDEZ

10. Adolescent Girls at the Tipping Point of Sustainable Development

DONNA L. GOODMAN

Box 10. Promoting Gender Equality through Sustainable Agricultural Production and Food Security

AGNES A. BABAGURA

Box 11. The Impact of Commercialization on Women's Access to Land in Ghana - A Case Study on Land Rights

TRACY HIGGINS AND JEANMARIE FENRICH

Box 12. Gender, Water and Sanitation SUSAN BAZILLI AND OLIMAR MAISONET-GUZMÁN

Box 13. Multidimensional Measurement, Women's Empowerment and Food Security SABINE ALKIRE

Reprinted with kind permission of UNDP 